\title{
EXPECTED FLORISTIC CHANGES IN HYGRO-CRYOPHILIC AND SNOWBED PLANT COMMUNITIES CAUSED BY CLIMATE CHANGE AND HUMAN IMPACT IN THE ROMANIAN CARPATHIANS
}

\author{
Ilie-Adrian STOICA ${ }^{1}$, Nicolae HODOR ${ }^{2}$, Traian TUDOSE ${ }^{2}$, Gheorghe COLDEA ${ }^{1}$ \\ ${ }^{1}$ Institute of Biological Research, Department of Taxonomy and Ecology, RO-400015 Cluj-Napoca, Romania \\ ${ }^{2}$ Babeş-Bolyai University, Department of Physical and Technical Geography, \\ Faculty of Geography, Clinicilor Str. 5-7, RO-400006 Cluj-Napoca, Romania \\ e-mail: gheorghe.coldea@icbcluj.ro
}

\begin{abstract}
In the Romanian Carpathians, there are only 6 massifs where glacial forms (valleys and cirques) occupy sufficiently large areas to support typical high altitude wetlands and snowbed vegetation. We have analyzed 424 relevées with this type of vegetation published in Romanian literature in the past century from these massifs. The cryophilic vegetation was grouped in 17 plant associations, 4 alliances and 3 Natura 2000 habitats. A total of 150 subalpine-alpine plant species (11 endemic) were registered in these communities $(27 \%$ of the total 550 high mountain taxa found in the entire Romanian Carpathian range). Future scenarios for the glacial landforms of the Carpathians suggest a temperature increase of about $2.5^{\circ} \mathrm{C}$ in 2050 and $3^{\circ} \mathrm{C}$ in 2070 . Species adapted to cool humid environments (Soldanella rugosa, Soldanella pusilla, Lychnis nivalis, Carex lachenalis, Chrysosplenium alpinum, Carex nigra subsp. dacica, Carex pyrenaica, Carex bicolor, Juncus castaneus, Juncus triglumis, Plantago gentianoides) are the most exposed to the threat of climate warming, as the disappearance of their typical habitat would mean extinction. Aside from the endemic flora, other cryophilic alpine taxa are also threatened. Natura 2000 habitats typical to these landforms $\left(6150,7240^{*}\right.$ and 3220) are being monitored in all 6 massifs, but there are no current administrative measures to monitor the presence of cryophilic species or plans to place glacial landforms under strict protection (IUCN category 1a), measures needed as human impact is more and more present at high altitudes.
\end{abstract}

Keywords: glacial landforms, high altitude wetlands, endemic species, alpine and boreal habitats, temperature projections, extinction risk, snow depth, plant diversity

\section{Introduction}

Cryophilic and snowbed plant communities occur in many ranges of the Romanian Carpathians, but are typical and occupy larger areas only in the 6 massifs with well-developed glacial land forms: Rodna, Făgăraș, Parâng, Retezat, Țarcu and Godeanu. They can be assigned to 3 Natura 2000 habitats $(6150,7240 *, 3220)$, all characterized by a pronounced biogeographical fragmentation. All Natura 2000 habitats which have been identified and described in the Romanian Carpathians $[16,14]$ are fragmented to a certain degree, due to natural (climate and biotic interactions) or anthropic causes. Alpine and subalpine environments, which are naturally fragmented, are some of the most exposed to climate impact $[18,15]$.

While the main source for fragmentation of cryophilic and snowbed communities is natural (caused by the climate and biotic interactions such as competition, dispersal limitations, etc.), they have also suffered from human activities. The anthropic impact in the Carpathian 
range has started with early human populations, which begun to transform forested areas in pastures [34]. The wood was used for housing and energy, while the pastures were used as food source for livestock during summer. As population reached modern day numbers, the range and intensity of impacts has increased, reaching the subalpine and alpine regions as well. The most destructive impact on high altitude vegetation has been the extensive deforestation of the subalpine shrub belts (characterized by Pinus mugo and Juniperus communis ssp. alpina). These habitats, which once occupied extensive areas, while not completely destroyed (by logging or by using fire), have been significantly reduced in order to expand the mountain pasture area. The secondary pasture communities installed in the deforested areas are dominated by a few species (e.g. Nardus stricta, Deschampsia flexuosa, Festuca nigrescens), and have a small floristic diversity index compared to natural subalpine pastures [11].

The deforestation of the subalpine belt has triggered large scale soil erosion processes of the upper mountain slopes and has reduced significantly the water retaining capacity of the soil in the subalpine belt. As the organic layer above the soil has been reduced and in some cases even completely destroyed [8], the general hydrology of these regions has changed. As a consequence, the cover of high altitude wet areas, usually found near springs and rivulets, has decreased in the last decades in the Romanian Carpathians, a decrease which is accompanied by a loss of rare plant species [35]. This process is intensified by the present day climate warming [26], as some subalpine and alpine springs go dry during the summer, threatening the future existence of cryophilic species, which are strongly related to this type of habitat. Changes in snow cover duration and snow depth are expected to progress in the coming decades toward higher altitudes, possibly even in glacial cirques or in other landforms which currently harbor such plant species.

The ecology and biogeography of these species in the Carpathians needs to be better understood. This is even more valid for plants which are endemic for such environments, and may significantly or completely go extinct with their habitat. Today, adding to the destructive actions on the wet and nival habitats, intensive grazing with sheep is practiced on large areas. This causes plant root damage, as well as soil compacting processes [3], and has the potential to aggravate the existing climate pressure on the habitat types in question.

\section{Material and Methods}

\section{Study area}

The Romanian Carpathians are a continuous mountain range, characterized by significant altitudinal variation, with large continuous portions of lower altitudes, especially in the Eastern part. Glaciation landforms have been confirmed in 11 mountain massifs [41], of which 6 are truly representative (Fig. 1). Thus, we have taken these 6 massifs into consideration for our analysis. From the Eastern Romanian Carpathians: Rodna Mts. [37, 27]. In the Southern Romanian Carpathians: Făgăraș Mts. [29, 32], Parâng Mts. [41, 17], Retezat Mts. [29, 39], Godeanu Mts. [38, 30], Țarcu Mts. [30].

Quaternary glaciation in the Romanian Carpathians has occurred in two distinct periods: Riss (cca. 300,000 to 130,000 years ago) - when valley glaciers have formed, and Würm cca. 115,000 to 10,000 years ago), when high altitude glaciers have formed [40, 37, 27, 24]. The general consensus of existing studies places the lower limit of perennial snow in the Carpathian range during Riss, at an elevation of 1550-1600 m.s.m.. The same studies consider the perennial 
snow line during the Würm period at a higher altitude, of 1850-1900 m.s.m. We have digitized the glacial land forms found in the Romanian Carpathians, based on information found in the literature [38, 41, 37, 27, 32, 17, 39, 30], using satellite imagery and Romanian Topographic maps (1:25.000), in ArcGIS software [44]. This information was used to calculate average altitude of glacial landforms per massif, as well as the area occupied by each glacial landform (in hectares) (Tab. 1).

Table 1: Characteristics of the glacial landforms in the Romanian Carpathians

\begin{tabular}{ccccc}
\hline No. & Massif & $\begin{array}{c}\text { Avg. Altitude } \\
\text { m.s.m. }\end{array}$ & $\begin{array}{c}\text { Total area } \\
\text { ha }\end{array}$ & $\begin{array}{c}\text { Avg. Area } \\
\text { ha }\end{array}$ \\
\hline $\mathbf{1}$ & Făgăraş & 2101.92 & 10186.09 & 59.91 \\
$\mathbf{2}$ & Godeanu & 1947.85 & 2571.82 & 65.94 \\
$\mathbf{3}$ & Parâng & 2049.19 & 2386.62 & 56.82 \\
$\mathbf{4}$ & Retezat & 2059.62 & 3776.51 & 94.41 \\
$\mathbf{5}$ & Rodna & 1821.91 & 2703.42 & 87.2 \\
$\mathbf{6}$ & Țarcu & 1923.05 & 2579.50 & 71.65 \\
\hline
\end{tabular}

To complete the regional specificity of the glaciation phenomenon, we also emphasize that the size of glacial cirques in the Romanian Carpathians varies between the Eastern rim $0.85-4 \mathrm{~km}^{2}$ in the Rodna Mts. [27] and the Southern rim, 3.5-40 $\mathrm{km}^{2}$ in the Retezat Mts. [40].

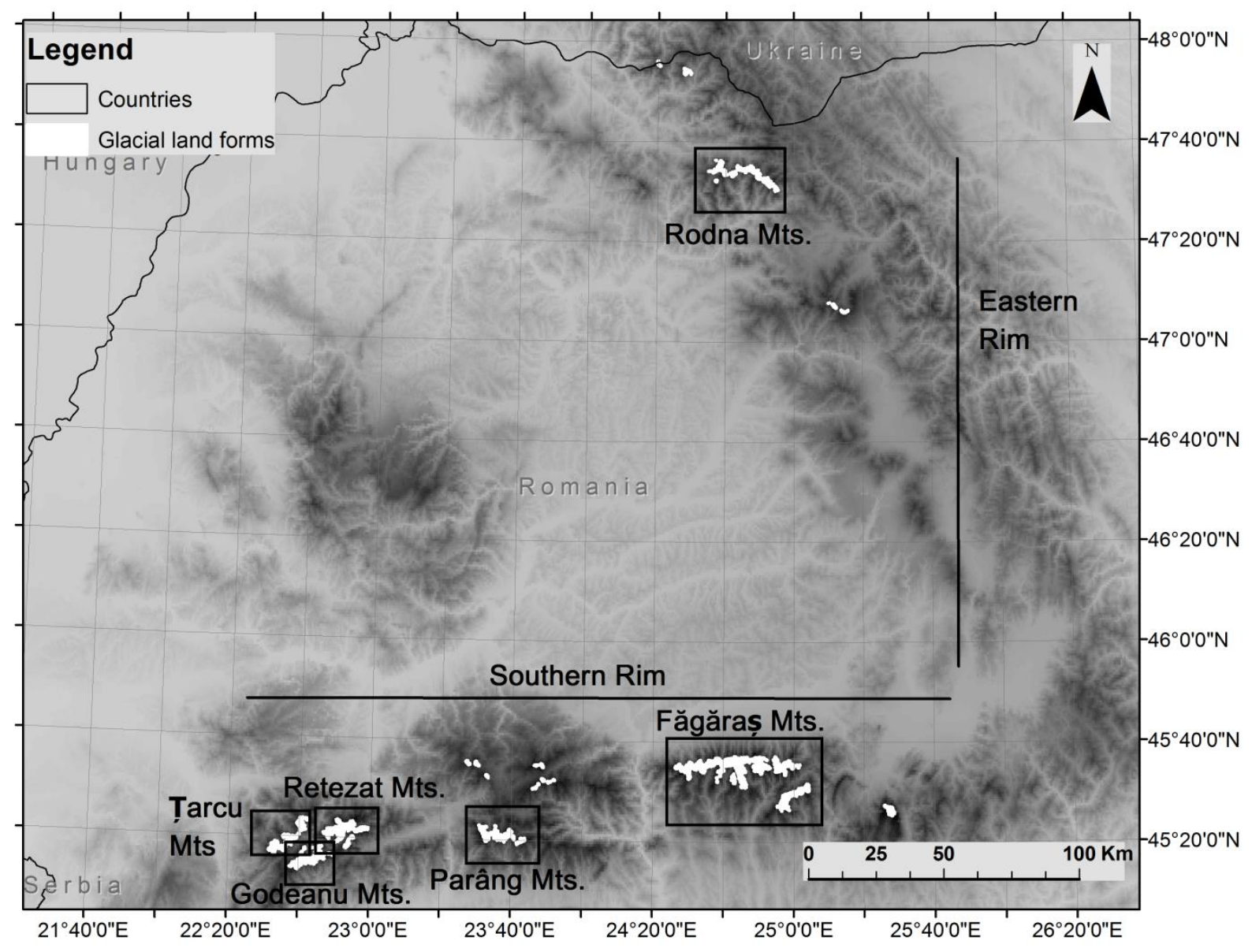

Fig. 1: Glacial landforms in the Romanian Carpathians, by massif 


\section{Phytocoenosis investigation}

The floristic and phytocoenotic database with plant communities typical to glacial and pre-glacial landforms from the 6 mountain massifs has been compiled from literature data published by several geo-botanical experts in the past few decades $[6,4,42,9,1,33]$.

Table 2: The floristic structure of cryophilic and cryo-hygrophilic plant communities - plant species constancy expressed as classes from 1 to 5 (Alliances: $\mathbf{S H}$ - Salicion herbaceae, CM - CardaminoMontion, CF - Caricion fuscae, CB - Caricion bicolori-atrofuscae)

\begin{tabular}{|c|c|c|c|c|c|c|c|c|c|c|c|c|c|c|c|c|c|}
\hline \multirow{2}{*}{$\begin{array}{l}\text { ALLIANCE } \\
\text { Association no. }\end{array}$} & \multicolumn{8}{|c|}{ SH } & \multicolumn{5}{|c|}{$C M$} & \multicolumn{3}{|c|}{$C F$} & $C B$ \\
\hline & 1 & 2 & 3 & 4 & 5 & 6 & 7 & 8 & 9 & 10 & 11 & 12 & 13 & 14 & 15 & 16 & 17 \\
\hline No. of relevés & 15 & 31 & 19 & 27 & 10 & 24 & 39 & 16 & 17 & 91 & 40 & 25 & 24 & 13 & 20 & 8 & 5 \\
\hline
\end{tabular}

Char. ass.

Polytrichum sexangulare

Salix herbacea

Arenaria biflora

Soldanella pusilla

Soldanella rugosa

Poa granitica ssp.

disparilis

Poa supina

Luzula alpino-pilosa ssp. obscura

Nardus stricta

Polytrichum alpinum

\section{Salicion et Salicetalia \\ herbaceae}

Gnaphalium supinum

Ranunculus crenatus

Kiaeria starkei

Carex pyrenaica

Crysanthemum alpinum

Kiaeria falcata

\section{Salicetea herbaceae}

Cerastium cerastioides

Sedum alpestre

Veronica alpina

Oligotrichum hercinicum

Anthelia juratzkana

$\begin{array}{llllllll}5 & 1 & 1 & 1 & 3 & 1 & 1 & 2 \\ 2 & 5 & . & 1 & 1 & 1 & 1 & . \\ . & . & 5 & 1 & . & . & . & . \\ 2 & 2 & 2 & 5 & . & 1 & 2 & 2 \\ 2 & 2 & . & . & 5 & 1 & 1 & 2 \\ 1 & . & . & . & 3 & . & 1 & . \\ . & 1 & . & . & . & 4 & . & 1 \\ 3 & 2 & 3 & 2 & 5 & 1 & 5 & 3 \\ . & . & 2 & 3 & 1 & 2 & . & 5 \\ . & . & . & . & . & . & . & 3\end{array}$

Lychnis nivalis

Epilobium

anagallidifolium

\section{Char. ass.}

Cardamine opizii

Chrysosplenium alpinum

Philonotis seriata

Caltha laeta

Cratoneuron commutatum 


\begin{tabular}{|c|c|c|c|c|c|c|c|c|c|c|c|c|c|c|c|c|c|}
\hline ALLIANCE & & & & $S H$ & & & & & & & $C M$ & & & & & & $C B$ \\
\hline Association no. & 1 & 2 & 3 & 4 & 5 & 6 & 7 & 8 & 9 & 10 & 11 & 12 & 13 & 14 & 15 & 16 & 17 \\
\hline
\end{tabular}

Doronicum carpaticum

Saxifraga aizoides

Silene pusilla

Cratoneuron filicinum

Cardamino-Montion et Montio-Cardaminetalia

Saxifraga stellaris

Viola biflora

Epilobium nutans

Epilobium alsinifolium

Chrysosplenium

alternifolium

Bryum pseudotriquetrum

Stellaria nemorum

Saxifraga heucherifolia

Cardamine amara

Philonotis fontana

Philonotis caespitosa

Veronica beccabunga

Brachytecium rivulare

Scapania undulata

Stellaria uliginosa

Pinguicula vulgaris

Char. ass.

Carex $n$. ${ }^{*}$ dacica

Plantago gentianoides

Drepanocladus fluitans

Drepanocladus

exannulatus

Eriophorum scheuchzeri

Carex lachenali

\section{Caricion et Caricetalia} fuscae

Carex canescens

Juncus filiformis

Agrostis canina

Carex echinata

Aulacomnium palustre

Sphagnum subsecundum

Carex rostrata

Char. ass.

Carex bicolor 


\begin{tabular}{|c|c|c|c|c|c|c|c|c|c|c|c|c|c|c|c|c|c|}
\hline ALLIANCE & & & & $S H$ & & & & & & & $C M$ & & & & & & $C B$ \\
\hline Association no. & 1 & 2 & 3 & 4 & 5 & 6 & 7 & 8 & 9 & 10 & 11 & 12 & 13 & 14 & 15 & 16 & 17 \\
\hline
\end{tabular}

Caricion bicolori-

atrofuscae et

\section{Tofieldietalia}

Juncus castaneus

Juncus alpinus

Trifolium badium

Bartsia alpina

Selaginella selaginoides

\section{Scheuchzerio-Caricetea} nigrae

Cardamine p. * rivularis Juncus triglumis

Parnassia palustris

Dactylorhiza cordigera

Luzula sudetica

Sphagnum recurvum

Sphagnum teres

Comarum palustre

Menyanthes trifoliata

Calliergon stramineum

Dactylorhiza maculata

Carex dioica

Campylium stellatum

\section{Sphagnetalia}

Eriophorum vaginatum

Polytrichum commune

Polytrichum strictum

Carex pauciflora

\section{Compagnes}

Deschampsia caespitosa

Ligusticum mutellina

Poa alpina

Taraxacum alpinum

Primula minima

Taraxacum nigricans

Geum montanum

Agrostis rupestris

Festuca airoides

Homogyne alpina

Veratrum album

Anthoxanthum alpinum

Carex curvula 


\begin{tabular}{|c|c|c|c|c|c|c|c|c|c|c|c|c|c|c|c|c|c|}
\hline ALLIANCE & & & & $S H$ & & & & & & & CM & & & & $\boldsymbol{F}$ & & $C B$ \\
\hline Association no. & 1 & 2 & 3 & 4 & 5 & 6 & 7 & 8 & 9 & 10 & 11 & 12 & 13 & 14 & 15 & 16 & 17 \\
\hline
\end{tabular}

Potentilla a.* chrysocraspeda

Chaerophyllum hirsutum

Myosotis laxa

Campanula alpina

Juncus trifidus

Polygonum viviparum

Achillea schuri

Lychnis flos-cuculi

Veronica baumgarteni

Hieracium alpinum

Phyteuma confusum

Rhododendron myrtifolium

Arabis alpina

Soldanella major

Aconitum tauricum

Senecio subalpinus

Crepis paludosa

Bryum bimum

Drepanocladus uncinatus

Phleum alpinum

Pulsatilla alba

Poa media

Mnium punctatum

Galium uliginosum

Doronicum columnae

Alchemilla glabra

Myosotis scorpioides

Ranunculus repens

Carex flava

Eriophorum latifolium

Dicranella heteromalla

Diplophyllum taxifolium

Oreochloa disticha

Pleuroclada islandica

Gentiana punctata

Saxifraga androsacea

Campanula polymorpha

Alchemilla fissa

Saxifraga hieracifolia

Ranunculus montanus

Doronicum stiriacum

Valeriana simplicifolia

Juncus effusus 


\begin{tabular}{|c|c|c|c|c|c|c|c|c|c|c|c|c|c|c|c|c|c|}
\hline ALLIANCE & & & & $S H$ & & & & & & & $C M$ & & & & $F$ & & $C B$ \\
\hline Association no. & 1 & 2 & 3 & 4 & 5 & 6 & 7 & 8 & 9 & 10 & 11 & 12 & 13 & 14 & 15 & 16 & 17 \\
\hline
\end{tabular}

\author{
Equisetum palustre \\ Carex pallescens \\ Rumex alpinus \\ Poa trivialis \\ Cardamine mathiolii \\ Alchemilla vulgaris \\ Viola dacica \\ Polygonum bistorta \\ Geum rivale \\ Sphagnum girgensohnii
}

1. Polytrichetum sexangularis Frey 1922: 10 rel. from Coldea 1990 (Rodna Mountains), 5 rel from PușcaruSoroceanu 1981 (Făgăraș Mountains). 2. Salicetum herbaceae Rübel 1911: 5 rel. from Pușcaru et al. 1956 (Bucegi Mountains), 5 rel. from Boșcaiu 1971 (Țarcu-Godeanu Mountains), 12 rel. from Pușcaru-Soroceanu 1981 (Făgăraș Mountains), 9 rel. from Coldea (Rodna Mountains). 3. Arenarietum biflorae Voik 1976: 10 rel. from Voik 1976 (Făgăraș Mountains, 4 rel. from Drăgulescu 1995 (Sadu Valley). 4. Soldanello pusillae-Ranunculetum crenati (Borza 1931) Boșcaiu 1971: 14 rel. from Boșcaiu 1971 (Țarcu-Godeanu Mountains), 8 rel. from Resmeriţă 1976 (Retezat Mountains), 5 rel. from Voik 1976 (Făgăraș Mountains). 5. Soldanello rugosae-Ranunculetum crenati Coldea (1985) 2017: 10 rel. from Coldea 1985 (Rodna Mountains). 6. Poo supinae-Cerastietum cerastioidis (Söyr. 1954) Oberd. 1957: 8 rel. from Resmeriță 1976 (Retezat Mountains), 11 rel. from Boșcaiu 1971 (Țarcu-Godeanu) Mountains), 5 rel. from Coldea 1985 (Rodna Mountains), 10 rel. from Alexiu 1998 (Iezer-Păpușa Mountains). 7. Luzuletum obscurae (Szafer et al. 1927) Dúbravcová 2000: 8 rel. from Coldea 1985 (Rodna Mountains), 7 rel. from Boșcaiu 1971 (Țarcu-Godeanu Mountains), 8 rel. from Resmeriță 1976 (Retezat Mountains), 14 rel. from Borza 1934 (Retezat Mountains), 2 rel. from Drăgulescu 1995 (Sadu Valley). 8. Nardo-Gnaphalietum supini Bartsch 1940: 8 rel. from Coldea 1985 (Rodna Mountains), 8 rel. from Resmeriță 1976 (Retezat Mountains). 9. Cardaminetum opicii Szafer et al. 1923: 10 rel. from Coldea 1990 (Rodna Mountains), 6 rel. from Boșcaiu 1971 (Țarcu-Godeanu Mountains), 1 rel. from Voik 1976 (Făgăraș Mountains). 10. Chrysosplenio alpini-Saxifragetum stellaris Pawl. et Wal. 1949: 8 rel. from Coldea 1990 (Rodna Mountains), 18 rel. from Voik 1976 (Făgăraș Mountains), 5 rel. from Pușcaru-Soroceanu et al. 1981 (Făgăraș Mountains), 25 rel. from Boșcaiu 1971 (Țarcu-Godeanu Mountains), 7 rel. from Boșcaiu et al. 1972 (Retezat Mountains), 13 rel. from Plămadă 1974 (Retezat Mountains), 10 rel. from Huml. et al. 1979 (Făgăraș Mountains). 11. Philonotido-Calthetum lactae (Krajina 1933) Coldea 1991: 7 rel. from Coldea 1990 (Rodna Mountains), 7 rel. from Sanda et al. 1997 (Piatra Craiului Mountains), 6 rel. from Pușcaru-Soroceanu et al. 1981 (Făgăraș Mountains), 10 rel. from Boșcaiu 1971 (Țarcu-Godeanu Mountains), 5 rel. from Boșcaiu et al. 1972 (Retezat Mountains), 5 rel. from Resmeriță 1970 (Vlădeasa Mountains), 5 rel. from Mihăilescu 2001 (Piatra Craiului Miuntains). 12. Philonotido-Saxifragetum stellaris Horv. 1949: 25 rel. from Boșcaiu 1971 (Țarcu-Godeanu Mountains). 13. Doronico carpatici-Saxifragetum aizoidis Coldea 1990: 11 rel. from Coldea 1990 (Rodna Mountains), 5 rel. from Olos 1982 (Piatra Rea), 5 rel. from Boșcaiu 1971 (Țarcu-Godeanu Mountains), 3 rel. from Coldea 1991 (Retezat Mountains), 5 rel. from Stancu 2005 (Făgăraș Mountains), 5 rel. from Neblea 2006 (Leaota Mountains). 14. Carici dacicae-Plantaginetum gentianoides Boșcaiu et al. 1972: 8 rel. from Boșcaiu et al. 1972 (Retezat Mountains), 1 rel. from Borza 1934 (Retezat Mountains), 4 rel. from Coldea et Plămadă 1980 (Făgăraș, Rodna Mountains). 15. Carici dacicae-Drepanocladetum exannulati Boșcaiu et al. 1972: 8 rel. from Boșcaiu et al. 1972 (Retezat Mountains), 6 rel. from Borza 1934 (Retezat Mountains), 10 rel. from Coldea 1990 (Rodna Mountains), 2 rel. from Resmeriță 1973 (Rodna Mountains), 5 rel. from Alexiu 1998 (Iezer-Păpușa Mountains). 16. Eriophoretum scheuchzeri Rübel 1912: 8 rel. from Coldea 1990 (Rodna Mountains). 17. Swertio perennis-Caricetum bicoloris Coldea et al. 2008: 5 rel. from Coldea et al. 2008 (Rodna Mountains).

Cryophilic and hygro-cryophilic phytocoenosis were investigated using the method developed by Braun Blanquet (1964) [5]. The standard phytocoenotic relevée area in our study is $25 \mathrm{~m}^{2}$. In the phytocoenotic synthetic table (Tab. 2), the species constancy of occurrence (sensu Cristea et al. 2004 [13]) is expressed in arabic numbers (1-5). The phytocoenosis have been 
grouped into plant associations (communities) based on characteristic and dominant plant species, typical to the habitats under investigation. Aside from the characteristic species, several other plant taxa occurred more frequently in certain communities, allowing us to draw similarities between the different coenosis, and to group them into plant associations.

The floristic structure of the relevées was then used to group the associations into several syntaxonomic units. These units are distinct, and define the alpine and subalpine habitats which are the focus of this study, in a manner which is relevant to their structure and functioning [35]. For the accuracy of assigning the associations into alliances, we have used the Jaccard similarity index to observe the natural grouping of the communities (vegan package, R software) [31].

In order to assess the diversity of the communities, we have used the Shannon diversity index, for the constancy values of each plant association (using the renyi function, sensu Jost 2006 [22]).

The scientific name of all cormophyte taxa was considered after Ciocârlan 2009 [7].

\section{Climate data}

We have extracted temperature and precipitation data from yearly meteorological reports for the last 50 years at 2 weather stations, one in the eastern rim (Iezeru Pietrosului, 1785 m.s.m.), and one in the southern rim (Omului peak, 2500 m.s.m.). Snow cover trend for the two weather stations extracted from Carpatclim [36] were analyzed for trend (linear models) in $\mathrm{R}$ software, and used to predict the first years when snow cover will be possibly missing.

Using monthly climate data, we have calculated a yearly average for temperature and precipitation. Decadal means were also calculated, for each 10 years starting with the year 1961, until 2010. The results of these calculations are presented in two separate graphs. Data concerning snow depth and snow cover duration, referred to further in the material, are taken from the work of Micu D. M. et al. 2015 [26], and from existing databases (Carpatclim) [36].

Finally, future climate projections from 10 Global Circulation Models (GCMs) were taken into consideration (Tab. 3), in order to determine the most likely future scenario for the glacial landforms found in the Romanian Carpathians. Namely, we have used the bioclim 1 (Annual Mean Temperature), bioclim 11 (Mean Temperature of Coldest Quarter), bioclim 12 (Annual Precipitation) and bioclim 19 (Precipitation of Coldest Quarter) variables from the Worldclim dataset [20] produced by the GCMs, downscaled at 30 seconds (aprox. $1 \mathrm{~km}$ ), for all available scenarios (Representative Concentration Pathways [45], or RCPs - 2.6, 4.5, 6.0, 8.5). Climate information for the glacial landforms from the Romanian Carpathians was extracted in $\mathrm{R}$ software [46], using the raster package [19]. The dplyr package [43] was also used in handling the output data.

\section{Results}

Glacial landforms have developed in the Romanian Carpathians during the previous tens of thousands of years. They are more or less typical as a function of the altitude of each massif and of the altitudinal variability of these massifs (Tab. 1).

The 424 phytocoenotic relevées, published from glacial and periglacial landforms from the 6 massifs of the Romanian Carpathians, have been classified as belonging to 17 plant communities (associations) - using dominant and characteristic species. Further on, using species with similar ecological requirements, these 17 communities have been classified in 4 
alliances (Tab. 2, Tab. 4): Salicion herbaceae, Cardamino-Montion, Caricion fuscae, Caricion bicolori-atrofuscae [35, 10, 23].

Table 3: Global Circulation Models (GCMs) used from the Worldclim database [20]

\begin{tabular}{llll}
\hline No. & Name & Country & Code \\
\hline 1 & Beijing Climate Center Climate System Model & China & BCC-CSM1-1 \\
2 & Community Earth System Model & USA & CCSM4 \\
3 & Goddard Institute for Space Studies & USA & GISS-E2-R \\
4 & Met Office Hadley Center Atmosphere Model & UK & HadGEM2-AO \\
5 & Met Office Hadley Center Earth System Model & UK & HadGEM2-ES \\
6 & Japan Agency for Marine-Earth Science and Technology - & Japan & MIROC-ESM-CHEM \\
& Model for Interdisciplinary Research on Climate - Earth & & \\
7 & System Model - Atmospheric Chemistry & & \\
7 & Japan Agency for Marine-Earth Science and Technology - & Japan & MIROC-ESM \\
& Model for Interdisciplinary Research on Climate & \\
8 & Japan Agency for Marine-Earth Science and Technology - & Japan & MIROC5 \\
& Model for Interdisciplinary Research on Climate & Japan & MRI-CGCM3 \\
9 & Japan Meteorological Research Institute & Norway & NorESM1-M \\
10 & Norwegian Earth System Model & & \\
\hline
\end{tabular}

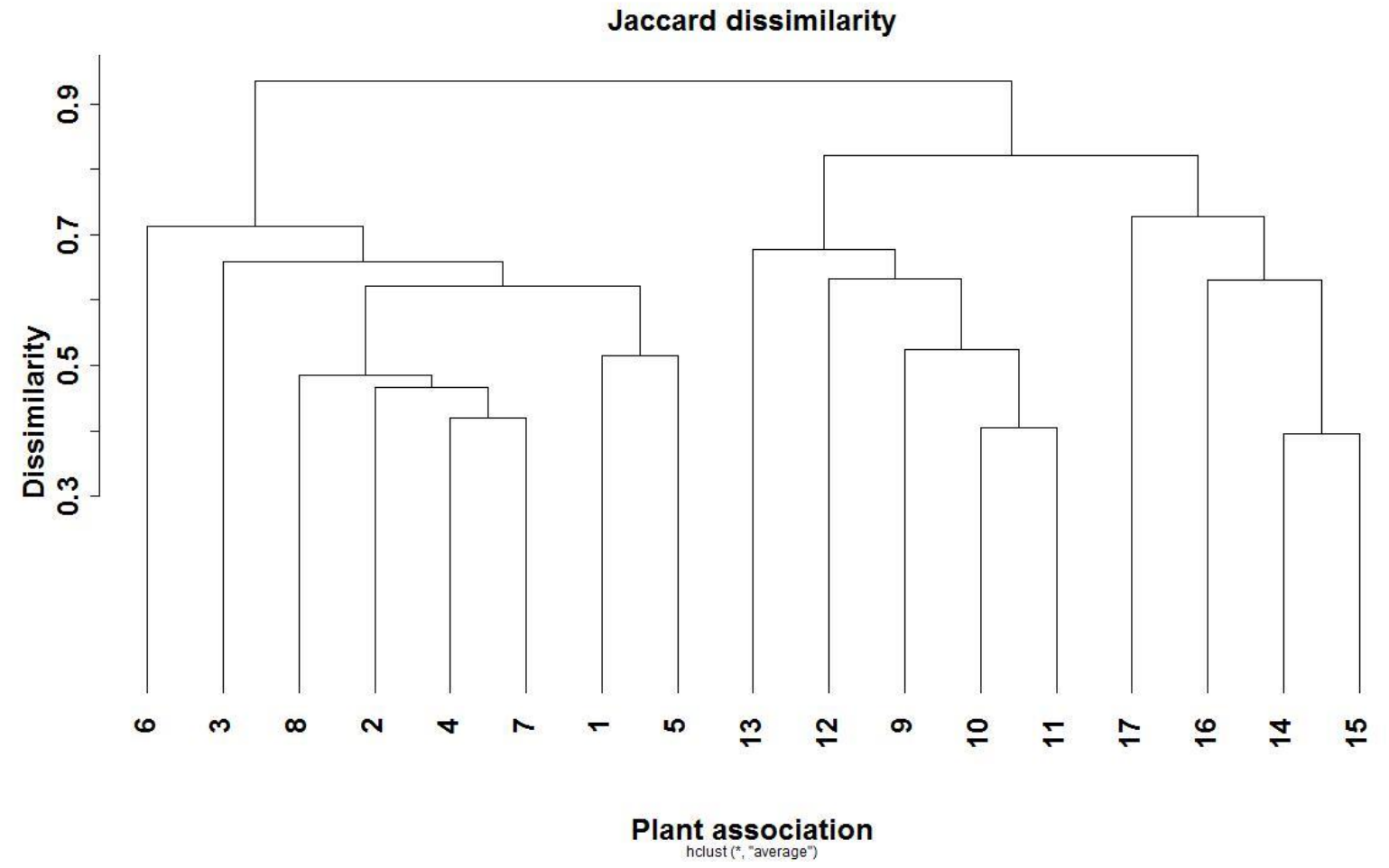

Fig. 2: Jaccard similarity of high altitude wetlands and snowbed plant communities in the Romanian Carpathians (number of association identical to Tab.4) 
Table 4: Plant communities with cryophilic vegetation, typically found in the glacial and peri-glacial landforms of the Romanian Carpathians.

\begin{tabular}{|c|c|c|c|c|}
\hline No. & Plant communities (associations) & $\begin{array}{c}\text { Altitude } \\
\text { (min-max) }\end{array}$ & $\begin{array}{c}\text { Species } \\
\text { number } \\
\text { (Endemic) }\end{array}$ & $\begin{array}{c}\text { Shannon } \\
\text { diversity (Jost } \\
\text { 2006) }\end{array}$ \\
\hline \multicolumn{5}{|c|}{ 1. Salicion herbaceae (Hab. 6150) } \\
\hline 1 & Polytrichetum sexangularis & $1800-2340$ & $23(3)$ & 3.01 \\
\hline 2 & Salicetum herbaceae & $2000-2450$ & $27(2)$ & 3.20 \\
\hline 3 & Arenarietum biflorae & $1700-2500$ & $18(2)$ & 2.74 \\
\hline 4 & Soldanello pusillae-Ranunculetum crenati & $1850-2250$ & $36(2)$ & 3.41 \\
\hline 5 & Soldanello rugosae-Ranunculetum crenati & $1800-2150$ & $26(5)$ & 3.11 \\
\hline 6 & Poo supinae-Cerastietum cerastioides & $1830-2050$ & $33(6)$ & 3.27 \\
\hline 7 & Luzuletum obscurae & $1900-2270$ & $45(4)$ & 3.63 \\
\hline 8 & $\begin{array}{l}\text { Nardo-Gnaphalietum supinae } \\
\text { 2. Cardamino-Montion (Hab. 3220) }\end{array}$ & $1700-2100$ & $31(3)$ & 3.27 \\
\hline 9 & Cardaminetum opicii & $1500-1900$ & $31(4)$ & 3.29 \\
\hline 10 & Chrysosplenio alpine-Saxifragetum stellaris & $1500-2200$ & $36(5)$ & 3.44 \\
\hline 11 & Philonotido-Calthetum laetae & $1550-1900$ & $41(3)$ & 3.52 \\
\hline 12 & Philonotido-Saxifragetum stellaris & $1550-1900$ & $35(1)$ & 3.38 \\
\hline \multicolumn{5}{|c|}{$\begin{array}{l}\text { 3. Caricion fuscae } \\
\text { (Hab. 3220) }\end{array}$} \\
\hline 14 & Carici dacicae - Plantaginetum gentianoidis & $1800-2200$ & $33(1)$ & 3.33 \\
\hline 15 & $\begin{array}{l}\text { Carici dacicae-Drepanocladetum } \\
\text { exannulati }\end{array}$ & $1850-2150$ & $44(1)$ & 3.67 \\
\hline 16 & Eriophoretum scheuchzeri & $1900-2100$ & $19(1)$ & 2.79 \\
\hline & $\begin{array}{l}\text { 4. Caricion bicolori-atrofuscae } \\
(\text { Hab. 7240*) }\end{array}$ & & & \\
\hline 17 & Swertio perennis-Caricetum bicoloris & $1665-1685$ & $28(1)$ & 3.20 \\
\hline
\end{tabular}

In the floristic structure of these plant associations, we could find a total of 150 plant species, most of which are characterized by a preference for subalpine-alpine habitats [12]. The dominant phyto-geographical elements in the structure of these communities are arcticcircumpolar species and alpine-central-european species, followed by eurasiatic species, Carpathian species and dacic-balkan species.

The Jaccard similarity reveals 2 large clusters (Fig. 2), one corresponding to the alliance Salicion herbaceae, and the other to the remaining 3 alliances, of which Cardamino-Montion and Caricion fuscae form two different sub-clusters. The alliance Caricion bicolori-atrofuscae is 
included in the Caricion fuscae cluster, based on the higher proportion of shared species.
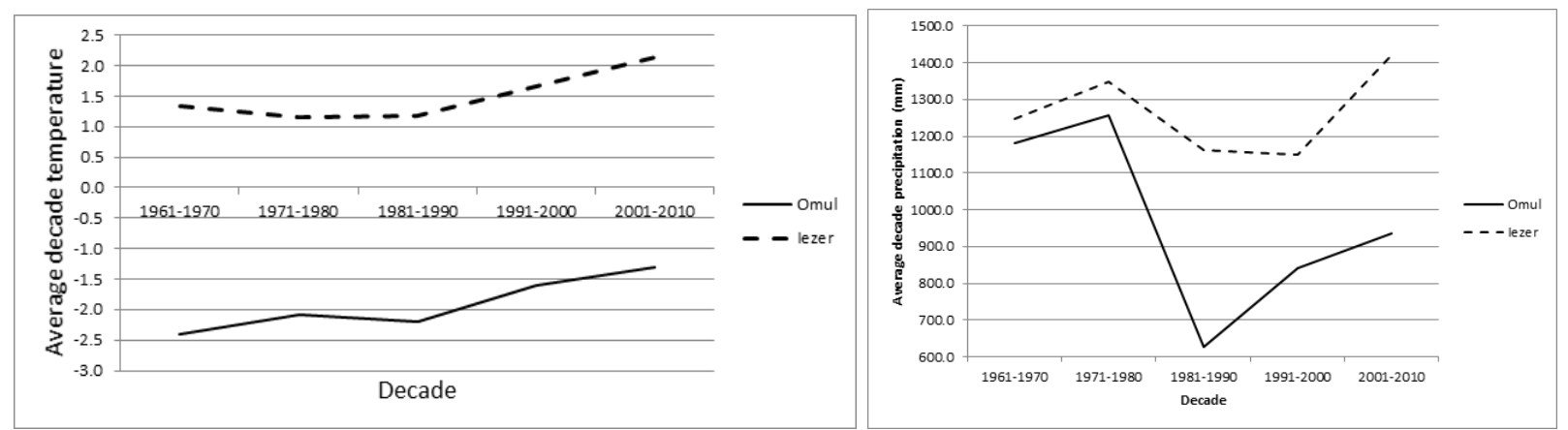

Fig. 3: Observed average decade temperature and precipitation trends in the past 50 years at 2 high mountain weather stations
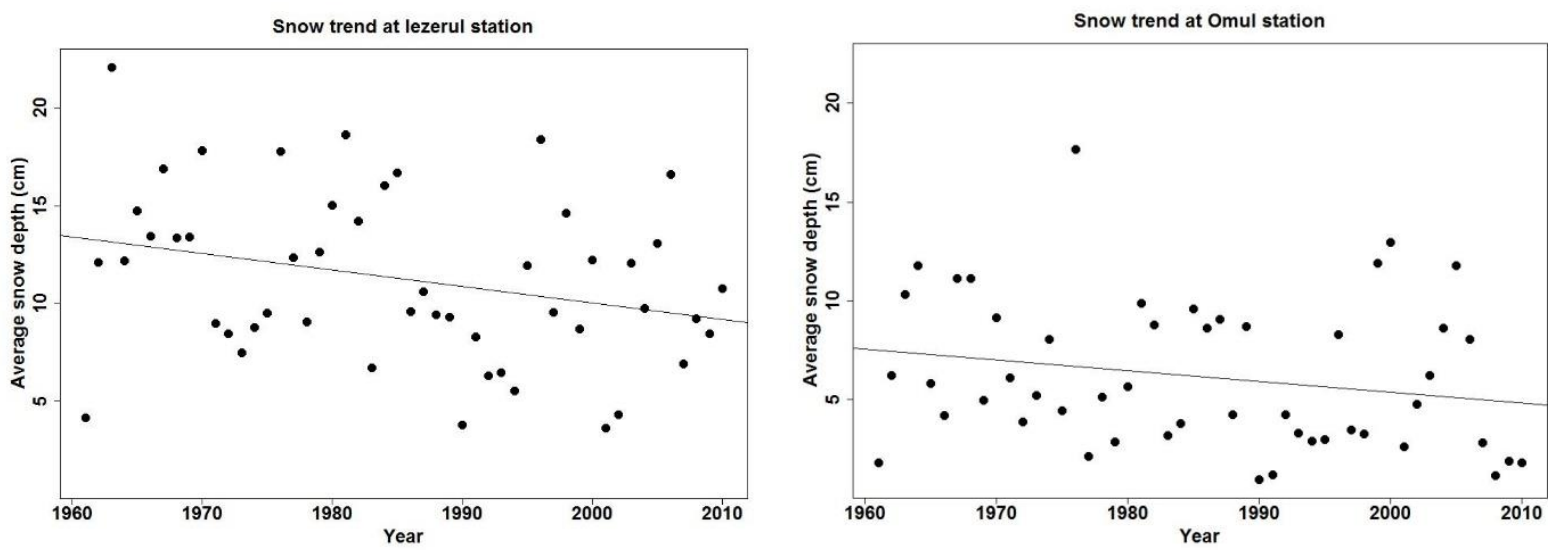

Fig. 4: Observed yearly snow depth trend in the past 50 years from the locations of the 2 weather stations (Carpatclim data).

While associations from the alliance Cardamino-Montion have the highest average number of species (on average 35.2 species), the highest species richness of individual associations is found in the alliances Salicion herbaceae (Luzuletum obscurae - 45 species) and Caricion fuscae (Carici dacicae-Drepanocladetum exannulati - 44 species) (Tab. 4). Shannon diversity varies between 2.74 (Arenarietum biflorae) and 3.67 (Carici dacicae-Drepanocladetum exannulati), and is in general correlated with species richness values.

Climate warming trends are registered for the entire Carpathian chain, with values ranging from +1 to $+6.2^{\circ} \mathrm{C}$ in the years 2050 and 2070. Precipitation may also increase overall and in the coldest quarter for the years 2050 and 2070, but there is higher variability observed for this type of data, as there are also models which predict a decrease (Fig. 5).

Snow depth is decreasing at both investigated stations, with an estimated $0.08 \mathrm{~cm} /$ year at Iezeru, and $0.054 \mathrm{~cm} /$ year at Omul (Fig. 4).

\section{Discussions}

The alliance Salicion herbaceae Br.-Bl. et Jenny 1926, is typical for glacial cirques (landforms with a pronounced concave aspect), where snow lasts until the end of spring (April).

We have delimited 8 plant associations in this alliance (Tab. 4). In the structure of these 

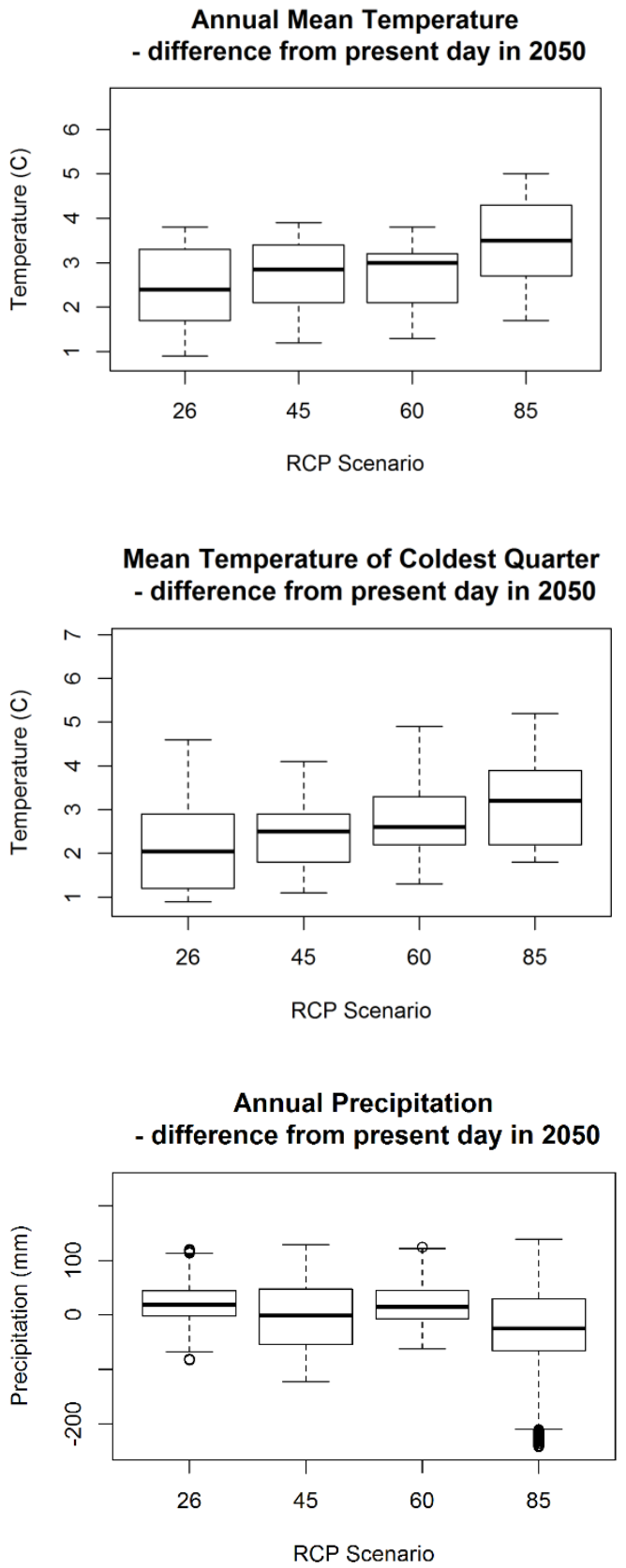

Precipitation of Coldest Quarter - difference from present day in 2050

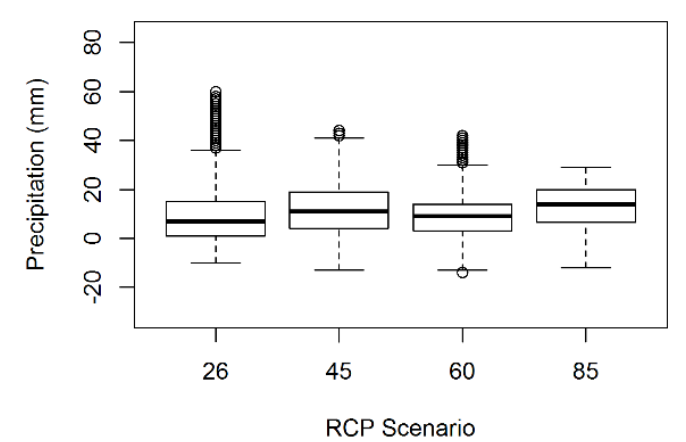

Annual Mean Temperature - difference from present day in 2070

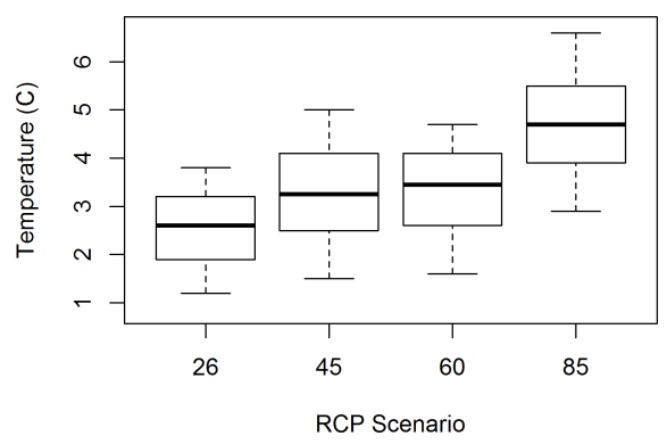

Mean Temperature of Coldest Quarter - difference from present day in $\mathbf{2 0 7 0}$

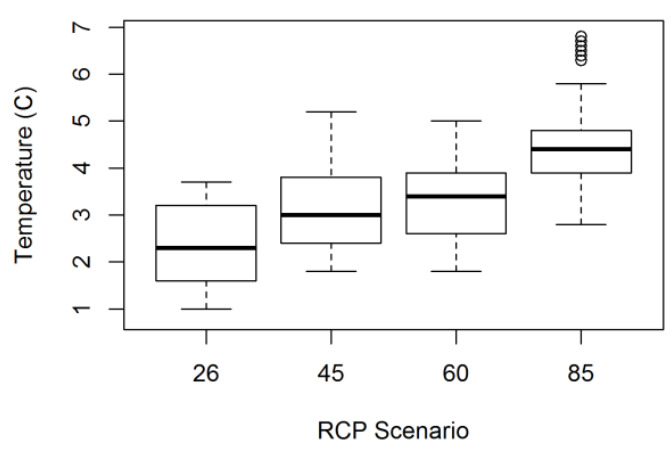

Annual Precipitation - difference from present day in $\mathbf{2 0 7 0}$

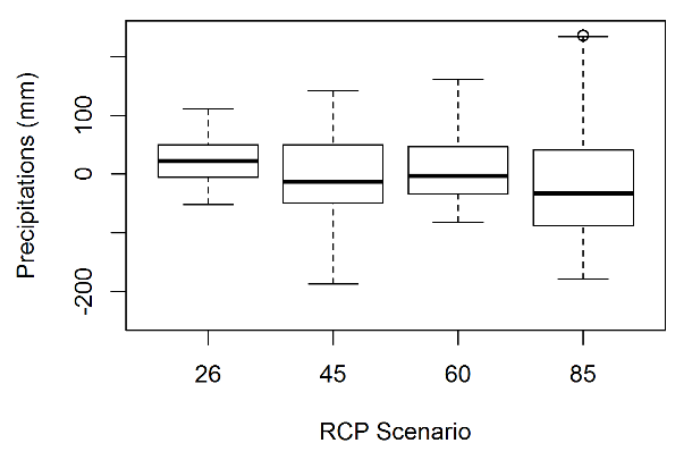

Precipitation of Coldest Quarter - difference from present day in 2070

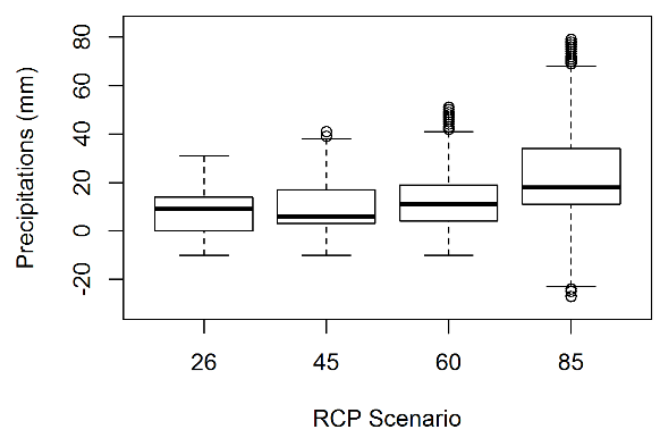

Fig. 5: Predicted climate change in the glacial cirques of the Romanian Carpathians 
communities 69 plant species have been registered, of which 60 cormophytes, most of them characteristic for subalpine-alpine environments, and an additional 9 cryophyte alpine bryophyte species. Of the 60 cormophytes, 9 species are endemic to the Carpathian range, of which 5 are endemic in the Romanian Carpathians (Lychnis nivalis, Soldanella rugosa, Achillea schurii, Poa granitica subsp. disparilis and Chrysosplenium alpinum). These species are strongly endangered by the warming climate, as their typical habitat (Natura 2000 Habitat 6150) is expected to reduce its cover in the Romanian Carpathians during the coming decades. Of the 8 plant associations specific for this habitat, the association Luzuletum obscurae (Szafer et al. 1927) Dúbravcová 2000 is the richest in species, with a high Shannon diversity index (3.63). It is also the most wide spread association of those analyzed within the alpine region of the Romanian Carpathians. The other 7 associations, although frequent in the alpine belt, occupy small areas, rarely over 30-40 $\mathrm{m}^{2}[10]$.

In the alliances Cardamino-Montion Br.-Bl. 1926 and Caricion fuscae W. Koch $1926 \mathrm{em}$. Klika 1934, we have grouped hygro-cryophilic plant communities typical to high altitude springs and subalpine moors (Quelle more). 8 plant associations have been included here, similar from a floristic point of view. There are 102 plant species present in their structure, of which 20 are bryophytes and 82 cormophytes. Plant communities in these 2 alliances are grouped together in Natura 2000 habitat 3220 [16]. Of the 82 cormophyte species, only 5 are considered to be endemic for the Romanian Carpathians [21]. Given that the plant communities grouped in these 8 associations live in the subalpine zone, in areas with no shrub cover, exposed to the solar insolation, both during summer and winter, it is expected that a warming climate may produce radical changes in the structure of this habitat. In the past 3 decades, several springs and subalpine bogs in the Rodna and Retezat National Park have been found completely dry during the summer season [10]. This is the main reason for which these communities continuously lose species, and in the near future they may even disappear from several mountain massifs.

The alliance Caricion bicolori-atrofuscae is in the same situation. Carex bicolor communities are found only in the Rodna Mountains, and the warming climate is expected to have drastic effects on these phytocoenosis.

The structural degradation of these wet-cryophilic communities is also caused by sheep grazing in the subalpine-alpine belts. In the summer period, subalpine springs and rivulets are frequently visited by sheep. The animals compact the soil with their hoofs and destroy many rare plant species found near these springs and high altitude bogs, such as: Juncus castaneus, Juncus triglumis, Carex dioica, Carex lachenali, Carex nigra ssp. dacica, Pinguicula vulgaris, Carex pauciflora [9].

The "in situ" persistence of these cryophyte and hygro-cryophyte plant communities depends on the values of the most important ecological factors which generate them, namely temperature and precipitation [28]. The analysis of historically observed climate trends for the past 50 years from the 2 high-altitude weather stations (Iezeru (1785 m.s.m.) and Omul (2500 m.s.m.)) revealed a clear climate warming process for both locations (Fig. 3). An analysis with data from all Romanian weather stations for the time period 1961-2010 [26] observed a warming trend of $0.5^{\circ} \mathrm{C}$ per decade in the last two decades. The same study made a projection for temperature change in the year 2050 , estimating an increase in temperatures of $2.5-3^{\circ} \mathrm{C}$. Our analysis of 10 Global Circulation Models for the glacial landforms of the Carpathians predicts also an average increase of $2.5^{\circ} \mathrm{C}$ for the year 2050, and $3^{\circ} \mathrm{C}$ for the year 2070 (Fig. 5). 
While the trend is clear for temperature, there is more of a debate regarding precipitations. First of all, precipitations generally have a varied spatial pattern compared to temperature. In Romania, there are several factors influencing the precipitation pattern [26]. The most important precipitation gradient is from the North West towards South East. Oceanic airflows travel from the North Atlantic towards Europe, and are characterized by high moisture. The western slopes of all the mountain ranges in the Romanian Carpathians (and the northern slope of the Southern Romanian Carpathians) usually receive more precipitation compared to the eastern / southern slopes. It is also worth noting that this airflow causes persistent cloud cover particularly in high-elevation areas during warm periods, as well as foehn effects on leeward slopes. A second important influence is from the South and South-West (from the Mediterranean Sea), with currents which brings warmer weather and high atmospheric instability. This influence is most evident on the southern slopes of the southern rim of the Carpathians. The third important influence is from north-eastern continental airflows, which are usually cold and dry, and affect the eastern slopes of the eastern rim of the Carpathians, being responsible for prolonged dry spells and for colder winters.

Analyzing the observed weather station record (Fig. 3), we can notice long precipitation cycles, spreading over decades. The Iezer station data shows a cyclic pattern, with precipitation currently returning to the higher values of the 1960s and 1970s. These values are representative for the mountains of northern Romania, where precipitation levels are usually higher, under the influence of the aforementioned oceanic airflow travel (North West to South East airflows). The Omul weather station is located in the eastern part of the southern rim of the Romanian Carpathians, at the "end" of the North West to South East rainfall gradient. This weather station registered also a cyclic precipitation behavior, but with an overall downward trend, as current day precipitations did not come back to the previous levels of the 1960s and 1970s. An overall downward trend in precipitation has been observed also by other climatic analysis of Romanian climate $[28,25]$.

In future projections for the year 2050 in the Romanian Carpathians [26], precipitations were considered as varying around $+/-10 \%$ of current values. This is consistent with the output of our analysis, as the 10 Global Circulation Models show a limited increase in precipitation for the glacial regions of the Romanian Carpathians, but some results indicate a decrease. Most of these models suggest a slightly more humid future in the coldest quarter of the year (relevant for snow cover). The average increase of precipitations predicted in the coldest quarter for all GCMs and all RCPs is marginal (about $10 \mathrm{~mm}$ in 2050, and $15 \mathrm{~mm}$ in 2070). As the climate is warming, more and more of the forecasted increased precipitation may fall as rain, impacting existing snow.

There is also proof of lower incidence of snow cover which affects to a large extent mountain areas located below 1600-1700 m.s.m. [25]. In the eastern and southern rim of the Romanian Carpathians, above 1700 m.s.m., the maximum snow depth $(39-71 \mathrm{~cm})$ occurs currently in March while snow cover duration in the subalpine and alpine belts has been reduced to 4-4 1/2 months [26]. Starting with April, snow melts completely, and in June it can be found only on very small areas on the northern, shaded slopes. Our analysis (linear models) on the snow depth from the past 50 years at the 2 weather stations (Fig. 4) also indicated that it is possible to have years with no snow on the mountain tops by the end of the century (year 2100).

There is also an expectation of an increase in frequency of severe climatic events, such as 
droughts, which impact high altitude flora [26].

\section{Conclusions}

For most of the 17 plant communities which occur currently in glacial landforms across the Romanian Carpathians, even the most optimistic changes of climate conditions which have been forecasted are expected to be associated with changes in the floristic structure. While today these communities are characterized by a mixture of arctic alpine species and endemics for the Carpathian range, the warming climate is expected to bring increased competition from other plant species, which are more adjusted to the expected warmer temperatures. We consider that only in the most optimistic scenario (26 RCP, Representative Concentration Pathway), changes in these communities may be limited. This is the optimistic scenario for gas emissions, in which $\mathrm{CO}_{2}$ emissions would reach a maximum of $421 \mathrm{ppm}$ in the period 2010-2020, and would decline after this decade $[2,45]$. In all other scenarios, important changes are inevitable, as cryophilic and hygro-cryophilic plant species are usually narrowly specialized for cooler climate conditions, with snow persistence, and are poorly adapted for competing against other species.

The list of plant species threatened by these new conditions includes endemic species, such as Soldanella rugosa, Lychnis nivalis, Aconitum tauricum, Poa granitica ssp. disparilis, Chrysosplenium alpinum, Carex lachenali, Carex nigra ssp. dacica, and can be extended to cryophilic alpine taxa such as: Soldanella pusilla, Carex pyrenaica, Saxifraga hieraciifolia, Plantago gentianoides, Juncus castaneus, Juncus triglumis and Carex bicolor.

Additional threats for these species are an expected increase in the fragmentation of the habitats where they occur, and the existing pressure of grazing with sheep at high altitudes. Most of these glacial landforms are included in existing National Parks and Natura 2000 sites, but there has been no effort so far to monitor the presence of any of the species mentioned. In order to protect the habitats from grazing and excessive fragmentation, additional measures need to be taken into consideration, such as forbidding grazing inside the north facing glacial landforms. Moreover, in the two National Parks (Rodna and Retezat), the glacial landforms should be included in IUCN 1a category (Strict Nature Reserve). In the remaining four massifs (Parâng, Făgăraș, Țarcu, Godeanu), these landforms should be included in Botanical Reservations (IUCN category 3). The protection of the shrub belt should also be taken into consideration, at least in some areas, given its importance in retaining water in the subalpine belt and creating the proper habitat for many of the species requiring a humid cold environment.

Acknwoledgement: IAS \& GC acknowledge funding from the Romanian Ministry of Research - program PN16 19 Biodivers

\section{REFERENCES}

1. Alexiu, V., 1998, Vegetația masivului Iezer-Păpușa, Editura Cultura, Pitești

2. Busuioc, A., Bojariu, R., Caian, M., Cheval, S., Dutu, M., 2010, Variabilitatea şi schimbarea climei $\hat{\imath}$ România, Pro Universitaria, Bucureşti

3. Betteridge, K., Mackay, A. D., Shepherd, T. G., Barker, D. J., Budding, P. J., Devantier, B. P., Costall, D. A., 1999, Effect of cattle and sheep treading on surface configuration of a sedimentary hill soil, Australian Journal of Soil Research, 37(4): 743-760. doi:10.1071/SR97014 
4. Boșcaiu, N., 1971, Flora și vegetația munților Țarcu, Godeanu și Cernei, Editura Academiei, București

5. Braun-Blanquet, J., 1964, Pflanzensoziologie, Springer Vienna, Vienna. doi:10.1007/978-3-7091-8110-2

6. Buia, A., Păun, M., Pavel, C., 1962, Pajistile din masivul Parang si imbunatatirea lor, Editura AgroSilvică, București

7. Ciocârlan, V., 2009, Flora ilustrată a României. Pteridophyta et Spermatophyta, Ed. Ceres, București

8. Coldea, G., 1980, Rolul termodinamic al jnepenişurilor in menținerea echilibrului natural al etajului subalpin din Carpații Românești, Ocrotirea Naturii, 24(2): 165-168

9. Coldea, G., 1990, Munții Rodnei - studiu geobotanic, Editura Academiei, București

10. Coldea, G., 1997, Les associations végétales de Roumanie, Tome I, Les associations herbacees naturelles, Ed. Presa Universitară Clujeană, Cluj-Napoca

11. Coldea, G., Cristea, V., 1998, Floristic and community diversity of sub-alpine and alpine grasslands and grazed dwarf-shrub heaths in the Romanian Carpathians, Pirineos, 151-152: 73-82

12. Coldea, G., Stoica, I.-A., Puşcaş, M., Ursu, T., Oprea, A., 2008, Alpine-subalpine species richness of the Romanian Carpathians and the current conservation status of rare species, Biodiversity and Conservation, 18(6): 1441-1458. doi:10.1007/s10531-008-9488-z

13. Cristea, V., Gafta, D., Pedrotti, F., 2004, Fitosociologie, Presa Universitară Clujeană, Cluj-Napoca

14. Doniță, N., Paucă-Comănescu, M., Popescu, A., Mihăilescu, S., Biriş, I. A., 2005, Habitatele din România, Editura Tehnică Silvică, București

15. Engler, R., Randin, C. F., Thuiller, W., Dullinger, S., Zimmermann, N. E., Araújo, M. B., Pearman, P. B., Le Lay, G., Piedallu, C., Albert, C. H., Choler, P., Coldea, G., De LAMO, X., Dirnböck, T., Gégout, J.-C., Gómez-García, D., Grytnes, J.-A., Heegaard, E., Høistad, F., Nogués-Bravo, D., Normand, S., Puşcaş, M., Sebastiàn, M.-T., Stanisci, A., Theurillat, J.-P., Trivedi, M. R., Vittoz, P., Guisan, A., 2011, 21st century climate change threatens mountain flora unequally across Europe, Global Change Biology, 17(7): 23302341. doi:10.1111/j.1365-2486.2010.02393.x

16. Gafta, D., Mountford, O., 2008, Manual de interpretare a habitatelor Natura 2000 din România, Risoprint, Cluj-Napoca

17. Gheorghiu, D. M., Hosu, M., Corpade, C., Xu, S., 2015, Deglaciation constraints in the Parâng Mountains, Southern Romania, using surface exposure dating, Quaternary International, 388: 156-167. doi:10.1016/j.quaint.2015.04.059

18. Gottfried, M., Pauli, H., Futschik, A., Akhalkatsi, M., Barančok, P., Benito Alonso, J. L., Coldea, G., Dick, J., Erschbamer, B., Fernández Calzado, M. R., Kazakis, G., Krajči, J., Larsson, P., Mallaun, M., Michelsen, O., Moiseev, D., Moiseev, P., Molau, U., Merzouki, A., Nagy, L., Nakhutsrishvili, G., Pedersen, B., Pelino, G., Puscas, M., Rossi, G., Stanisci, A., Theurillat, J.-P., Tomaselli, M., Villar, L., Vittoz, P., Vogiatzakis, I., Grabherr, G., 2012, Continent-wide response of mountain vegetation to climate change, Nature Climate Change, 2(2): 111-115. doi:10.1038/nclimate1329

19. Hijmans, R. J., van Etten, J., 2012, raster: Geographic analysis and modeling with raster data. Retrieved from http://cran.r-project.org/package=raster

20. Hijmans, R. J., Cameron, S. E., Parra, J. L., Jones, P. G., Jarvis, A., 2005, Very high resolution interpolated climate surfaces for global land areas, International Journal of Climatology, 25(15): 1965-1978. doi:10.1002/joc. 1276

21. Hurdu, B. I., Pușcaș, M., Turtureanu, P. D., Niketić, M., 2012, Patterns of plant endemism in the Romanian Carpathians, Contribuții Botanice, 47: 25-38

22. Jost, L., 2006, Entropy and diversity, Oikos. doi:10.1111/j.2006.0030-1299.14714.x

23. Kliment, J., Jarolimek, I., Sibik, J., 2007, Mulgedio - Aconitetea Hadac et Klika, In J. Kliment, M. Valachovic (Eds.), Rastlinné spoločenstvá Slovenska. 4. Vysokohorská vegetácia. Veda

24. Kuhlemann, J., Dobre, F., Urdea, P., Krumre, I., Gachev, E., Kubik, P., Rahn, M., 2013, Last glacial maximum glaciation of the Central South Carpathian Range (Romania), Austrian Journal of Earth Sciences, 106(2): 83-95

25. Micu, D., 2009, Snow pack in the Romanian Carpathians under changing climatic conditions, Meteorology and Atmospheric Physics, 105(1): 1-16

26. Micu, D. M., Dumitrescu, A., Cheval, S., Birsan, M.-V., 2015, Climate of the Romanian Carpathians, Springer 
27. Mîndrescu, M., 2001, Fotoliul glaciar Lala (Masivul Rodnei), Ann. Univ. "Ştefan cel Mare” Suceava, Sect. Geografie, 10: 63-73

28. Morán-Tejeda, E., López-Moreno, J. I., Beniston, M., 2013, The changing roles of temperature and precipitation on snowpack variability in Switzerland as a function of altitude, Geophysical Research Letters, 40: 1-6. doi:10.1002/grl.50463

29. Niculescu, G., 1957, Urme glaciare și periglaciare la izvoarele văii Buta (Munții Retezat), Probleme de Geografie, 5: 395-397

30. Niculescu, G., Nedelcu, E., Iancu, S., 1960, Nouvelle contribution à l'étude de la morphologie glaciaire dans les Carpates roumaines, Recueil d'études géographiques. Editions Acad. R.P. Roumaines, Bucarest, : 29-43

31. Oksanen, J., Blanchet, F. G., Kindt, R., Legendre, P., Minchin, P. R., O’Hara, R. B., Simpson, G. L., Solymos, P., Stevens, M. H. H., Wagner, H., 2013, vegan: Community Ecology Package. Retrieved from http://cran.r-project.org/package=vegan

32. Posea, G., 1981, O singură glaciațiune în Carpați, St. și Cerc. Geol. Geogr., 28: 87-102

33. Pușcaru, S. E., Csürös, Ş., Pușcaru, D., Popova-Cucu, A., 1981, Die Vegetation der Wiesen und Weiden des Făgăraş-Gebirges in den Südkarpaten., Phytocoenologia, 9(2): 257-309

34. Resmeriță, I., 1953, Contribuții la studiul și punerea în valoare a pajiștilor acoperite de Juniperus, St. și Cerc. Șt. Cluj, 1-2

35. Rodwell, J. S., Schaminée, J. H. J., Mucina, L. P., Pignatti, S., Dring, J., Moss, D., 2002, The diversity of European vegetation. An overview of phytosociological alliances and their relationships to EUNIS habitats, National Reference Centre for Agriculture, Nature and Fisheries, Wageningen, (EC-LNV 2002/054). doi:ISBN 90-75789-10-6

36. Spinoni, J., Szalai, S., Szentimrey, T., Lakatos, M., Bihari, Z., Nagy, A., Németh, Á., Kovács, T., Mihic, D., Dacic, M., Petrovic, P., Kržič, A., Hiebl, J., Auer, I., Milkovic, J., Štepánek, P., Zahradnícek, P., Kilar, P., Limanowka, D., Pyrc, R., Cheval, S., Birsan, M. V., Dumitrescu, A., Deak, G., Matei, M., Antolovic, I., Nejedlík, P., Štastný, P., Kajaba, P., Bochnícek, O., Galo, D., Mikulová, K., Nabyvanets, Y., Skrynyk, O., Krakovska, S., Gnatiuk, N., Tolasz, R., Antofie, T., Vogt, J., 2015, Climate of the Carpathian Region in the period 1961-2010: Climatologies and trends of 10 variables, International Journal of Climatology, 35(7): 1322-1341. doi:10.1002/joc.4059

37. Sîrcu, I., 1978, Munţii Rodnei. Studiu morfogeografic, Ed. Acad. R.S.România, Bucureşti

38. Sîrcu, I., 1982, Câteva constatări noi privind relieful glaciar din Carpați. Valea Glaciară Cărni din Munții Godeanu., Bul. Soc. Geogr. Rom. Serie nouă, VI(LXXVI)

39. Urdea, P., 1985, Câteva aspecte ale reliefului periglaciar din munții Retezat, Analele Științifice ale Universității ,,Al. I. Cuza” Iași, 31(2): 73-76

40. Urdea, P., 1993, Considerații asupra manifestărilor glaciației cuaternare în munții Retezat, St. şi Cerc. Geogr., 40: 65-72

41. Urdea, P., Reuther, A., 2009, Some new data concerning the Quaternary glaciation in the Romanian Carpathians, Geographica Pannonica, 13(2): 41-52.

42. Voik, W., 1976, Vegetația alpină din valea Șerbotei (Munții Făgăraș), St. Com. Șt. Nat. Muz. Brukenthal, 20: $46-64$

43. Wickham, H., Francois, R., 2016, dplyr: A Grammar of Data Manipulation. Retrieved from https://cran.rproject.org/package $=$ dplyr

44. *** ESRI, 2010, ArcMap 10.0, ESRI, Environmental Systems Resource Institute, Redlands, California

45. *** IPCC, 2013, Climate Change 2013: The Physical Science Basis. Contribution of Working Group I to the Fifth Assessment Report of the Intergovernmental Panel on Climate Change, (T. F. Stocker, D. Qin, G.-K. Plattner, M. Tignor, S. K. Allen, J. Boschung, A. Nauels, Y. Xia, V. Bex, P. M. Midgley, Eds.), Cambridge University Press, Cambridge, United Kingdom and New York, NY, USA. doi:10.1017/CBO9781107415324

46. *** R, 2010, R: A language and environment for statistical computing, R Foundation for Statistical Computing, Vienna, Austria. Retrieved from http://www.r-project.org/ 


\title{
MODIFICĂRI ANTICIPATE ÎN STRUCTURA FLORISTICĂ A COMUNITĂŢILOR VEGETALE HIGRO- MICROTERME ȘI DE ZĂCĂTORI DE ZĂPADĂ DIN CARPAȚII ROMÂNIEI, CAUZATE DE SCHIMBĂRILE CLIMATICE ȘI DE IMPACTUL ANTROPIC
}

\begin{abstract}
(Rezumat)
Doar 6 masive din Carpații României au forme glaciare (văi şi circuri) pe suprafețe suficient de extinse pentru a adăposti vegetație criofilă tipică pentru zăcători de zăpadă și zone umede de altitudine. Analiza noastră a cuprins 424 de relevée cu astfel de vegetație publicate în literatura din România din ultimul secol (pentru aceste masive). Acest tip de vegetaţie criofilă a fost grupată în 17 asociaţii, 4 alianțe și 3 habitate Natura 2000. Un număr total de 150 de specii de plante alpine și subalpine (dintre care 11 endemice) au fost înregistrate în aceste comunităti ( $27 \%$ din totalul celor 550 de taxoni de altitudine găsiți în întregul lanț Carpatic din România). Scenariile viitoare pentru formele geografice glaciare din Carpaţi sugerează o creștere a temperaturii de circa $2.5^{\circ} \mathrm{C}$ în 2050 și $3^{\circ} \mathrm{C}$ în 2070. Speciile de plante adaptate la climatul rece și umed (Soldanella rugosa, Soldanella pusilla, Lychnis nivalis, Carex lachenalis, Chrysosplenium alpinum, Carex nigra subsp. dacica, Carex pyrenaica, Carex bicolor, Juncus castaneus, Juncus triglumis, Plantago gentianoides) sunt cele mai expuse la amenințarea unui climat în încălzire, dispariția habitatelor lor fiind echivalentul dispariției lor complete din Carpați. Pe lângă flora endemică, și alte specii criofile alpine sunt de asemenea amenințate. Habitatele Natura 2000 tipice acestor forme de teren $\left(6150,7240^{*}\right.$, 3220) sunt monitorizate în cele 6 masive, dar nu există măsuri administrative de monitorizare a prezenței speciilor de plante criofile, precum nu există nici planuri de a proteja strict formele geografice glaciare (categorie I IUCN), măsuri necesare mai ales ca urmare a impactului antropic din ce în ce mai pronunțat la altitudini ridicate.
\end{abstract}

Received: 13.11.2017; Accepted: 22.11.2017 